\title{
中性子捕捉療法のためのガドリニウム キャリアーに関する製剤学的研究
}

宮本 雅仁

\section{1. 研究を始めた動機}

近年，がん治療は早期発見及び治療技術の進歩に伴 い，腫瘍を取り除く延命治療だけでなく，治療後の quality of life (QOL) の向上が重要視されるように なってきた。中性子捕捉療法 (NCT) は, 非放射性元 素である放射線增感剂と生体外照射した生体障害性の 低い熱中性子が核反応（中性子捕捉反応：NCR）を起 こした結果, 放出される放射線で治療を行うがん放射 線療法である。NCT の最大の特徴は NCRにより飛 程 10 数 $100 \mu \mathrm{m}$ の放射線を放出するため, 放射線 の照射範囲を細胞レベルで制御可能な事である。従 って，放射線障害を最小限にとどめると共に QOL 向 上に有効である。すでに臨床応用されているホウ素 （B－10）を増感剤に用いたホウ素中性子捕捉療法 (BNCT) の場合，飛程が細胞直径 (約 $10 \mu \mathrm{m})$ に等し い $\alpha$ 線により腫瘍細胞を殺傷するため， B-10を腫瘍 細胞内に送達することが課題となる。一方，ガドリ ニウム（Gd-157）を増感剤に用いたガドリニウム中 性子捕捉療法（GdNCT）では，NCRにより飛程 100 $\mu \mathrm{m}$ 以上の $\gamma$ 線等を放出するため, $\mathrm{Gd}$ が腫瘍組織内 に存在しても熱中性子照射により腫瘍細胞殺傷効果か 期待できる。

\section{2. 研究遂行上感じたこと}

本研究は，細胞外に存在する Gd の NCT による腫

2000 年 4 月 26 日受付

神戸薬科大学製剂学研究室

（テ658-8558 神戸市東淶区本山北町 4-19-1）TEL 078-441-7531

\section{<著者紹介>}

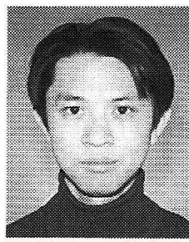

1992 年 3 月神戸学院大学薬学部卒業, 1994 年 3 月神戸学院大学大学院薬学研究科修士課程修 了, 1994年 4 月神戸学院大学大学院食品薬品総 合科学研究科博士後期課程入学, 1999 年 9 月博 士後期昩程修了，1999年12月神戸薬科大学製剂 学研究室博士研究員, 博士 (薬学)。

専門: 製剂学, 粉体工学。
痬細胞殺傷効果を証明することから研究が始まった。 研究を遂行する過程において, Gd 誘導体合成と有機 合成化学, マイクロカプセル (MC) とリピッドエマ ルション（LE）調製と製剤化技術，さらには担癌動物 を用いた体内動態評価と幅広い分野の知識と技術が必 要とされた。広範囲に及ぶ研究課題に着手することに 初め少なから好不安があったが，振り返ってみれば良 い経験であったと思う。

\section{3. 研究の主な成果}

腹水癌（V79）細胞を用いた in vitro 試験より, GdNCT で治療効果を獲得するためには約 $100 \mathrm{ppm}$ の腫瑝内 $\mathrm{Gd}-157$ 濃度が必要であると報告されてい た。本研究では in vivoでの腫瘍細胞殺傷効果を証明 すると共に，100ppm の腫瘍内 $\mathrm{Gd}$ 濃度を達成するへ く，気中懸濁被覆法（ワースター法）に上る $\mathrm{Gd}$ のリ ザーバー型 MC 化製剂及び体循環経由で腫瘍に Gd を 蓄積させるための LE 製剂の開発について検討した。

\section{1 In vivo 評価用高吸水性 Gd-DTPA-DM 含有} マイクロカプセルの調製

腫瘍細胞近傍の Gd が NCR を起こしても腫瘍細胞 殺傷効果が得られることを in vivo で証明するため, 製剂投与後熱中性子照射終了まで Gd $\mathrm{MC}$ 中に保 持可能な製剂の調製を検討した。MRI 造影剂ガト ペンテト酸シメグルミン（Gd-DTPA-DM）を芯乳 糖結晶 $(53-63 \mu \mathrm{m})$ に固定後, Ethyl CelluloseCholesterol (1:1) 膜で溶出制御した。吸湿性が強い Gd-DTPA-DM 粒子を大量被覆したため造粒粒子の 発生は避けられなかったが，最終製品の平均粒子径は $126 \mu \mathrm{m}$ であった。HPLCを用いたカラム法による溶 出試験の結果, $110^{\circ} \mathrm{C}$ で 30 分加熱処理した MC (75$106 \mu \mathrm{m} ）$ からの Gd-DTPA-DM の積算溶出率は 20 分で $9.3 \%$ に抑制できた。動物実験に要する時間が約 20 分であることから， $90 \%$ 以上の $\mathrm{Gd}$ は試験中 $\mathrm{MC}$ 内に保持されていたと推察される。本 MCと Ehrlich 
Table 1 Pharmacokinetic Parameters after Intraperitoneal Injection of Standard-Gd-DTPA-SA and High-Gd-DTPA-SA Emulsions

\begin{tabular}{|c|c|c|c|c|c|c|c|c|c|c|c|c|}
\hline \multirow{2}{*}{ Emulsions } & \multirow{2}{*}{$\begin{array}{c}\text { Particle size } \\
(\mathrm{nm})\end{array}$} & \multirow{2}{*}{$\begin{array}{c}\text { Dose } \\
\text { (mg Gd } / \mathrm{kg} \text { ) }\end{array}$} & \multirow{2}{*}{$\begin{array}{c}A U C \\
(\mu \mathrm{g} \cdot \mathrm{h} / \mathrm{m} l)\end{array}$} & \multirow{2}{*}{$\begin{array}{l}M R T \\
(\mathrm{~h})\end{array}$} & \multirow{2}{*}{$\begin{array}{c}V d_{\mathrm{ss}} \\
(\mathrm{m} l / \mathrm{kg})\end{array}$} & \multirow{2}{*}{$\begin{array}{c}C l_{\text {tot }} \\
(l /(\mathrm{h} / \mathrm{kg}))\end{array}$} & \multicolumn{2}{|c|}{$\mathrm{T} / \mathrm{B}$ ratio } & \multicolumn{2}{|c|}{$\mathrm{T} / \mathrm{Sk}$ ratio } & \multicolumn{2}{|c|}{$\mathrm{Sk} / \mathrm{B}$ ratio } \\
\hline & & & & & & & $24 \mathrm{~h}$ & $48 \mathrm{~h}$ & h & $\mathrm{h}$ & $4 \mathrm{~h}$ & $18 \mathrm{~h}$ \\
\hline$\pi$ & & 30 & & & & & 1 & .9 & 3.5 & 3.4 & & 0.9 \\
\hline Stand & & 3 & 228 & 15. & 4 & 13. & 1.5 & 21.4 & 6.2 & 5.2 & 0.3 & 4.1 \\
\hline Stan & $76.4 \pm$ & 30 & $4332 \pm$ & $22.3 \pm 0.6$ & $0.2 \pm 0.02$ & $7.0 \pm 0.7$ & 0.4 & 2.8 & 8.3 & 6.1 & 0.05 & 0.5 \\
\hline High-Gd HCO- 60 & $84.2 \pm 11.3$ & 60 & $4971 \pm 976$ & $16.0 \pm 0.5$ & $0.2 \pm 0.04$ & $12.5 \pm 2.5$ & 1.2 & 13.2 & 9.8 & 5.6 & 0.1 & 2.4 \\
\hline
\end{tabular}

Data are shown by mean \pm S.D. $(n=3-9)$.
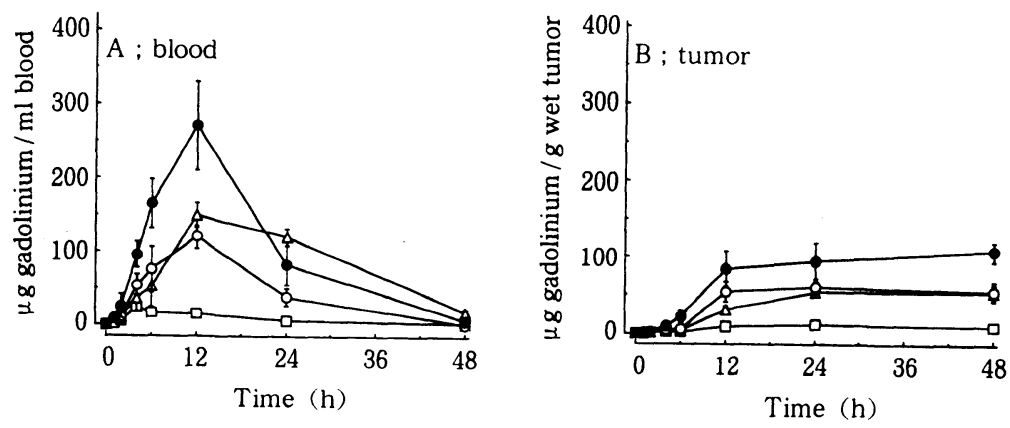

Fig. 1 Biodistribution of Gd-DTPA-SA Emulsions after Intraperitoneal Injection Symbols : $\square$, standard-Gd plain emulsion ; $\triangle$, standard-Gd Brij 700 emulsion ; O. standard-Gd HCO-60 emulsion ; 9 , high-Gd HCO-60 emulsion. $\mathrm{D}_{1}-179$ melanoma-bearing hamsters were used. Dose $: 2.0 \mathrm{~m} l(3.0 \mathrm{mg} \mathrm{Gd}$ for the standard-Gd formulation and $6.0 \mathrm{mg}$ Gd for high-Gd formulation)/hamster. Data are represented as the average \pm S.D. of 3-6 hamsters.

腹水癌練胞を腹胿内に同時投与し, 熱中性子を照射し た群のマウスは，コントロール群と比べて優位な延命 効果が観察され，秋根らにより報告された。この結果 より，GdNCT では腫瘍細胞近傍に存在する Gd に熱 中性子を照射しても，理論通り細胞殺傷効果が得られ ることが明らかとなった。

\section{2 Gd リザーバー型マイクロカプセルの調製}

$\mathrm{Gd}$ を腫瘍組織内に長期間とどめることができれ ば，腫瘍消失まで複数回熱中性子照射を行う治療スケ ジュールを確立できる。本治療法実現のため，Gdを 数週間〜数ヶ月間保持できる Gd リザーバー MC の調 製を検討した。芯粒子には比重 2.93 の重質炭酸カル シウム $(20-30 \mu \mathrm{m}), \mathrm{Gd}$ ソースにはガドペンテト酸 (Gd-DTPA) 及び Gd-DTPA にステアリルアミンを 導入した誘導体ガドペンテト酸ジステアリルアミド （Gd-DTPA-SA）を用いた。乳化重合法により合成 したアクリル系 3 元共重合体ラテックス中, 溶出傾 向が低い $9: 9: 4$ ポリ（アクリル酸エチル/メタクリル 酸メチル/メタクリル酸 2 -七ドロキシエチル）を溶
出抑止膜とした。Gdソースに関係無く粒度分布幅が 疶く，平均粒子径が約 $50 \mu \mathrm{m}$ の $\mathrm{MC}$ が調製できた。 日本薬局方のパドル法に従い等張リン酸緩衝液 $(\mathrm{pH}$ 7.4）中で溶出試験を行った結果，水溶性 Gd-DTPA の溶出は, 浸透圧による膜破壊のため約 3 時間で完 了した。一方, 水不溶性 Gd-DTPA-SA を用いるこ とで, 平均粒子径が $52 \mu \mathrm{m}, \mathrm{Gd}-\mathrm{DTPA}-\mathrm{SA}$ 含量が $38 \%, \mathrm{Gd}$ 漏出率が 60 日で $0.2 \%$ 以下の $\mathrm{Gd}$ リザー バーMC が調製できた。

\section{3. $3 \mathrm{Gd}$ 含有エマルションの調製とその体内動態 評価}

Gd を腫瘍組織に体循環経由で集積させ腫瘍内 Gd 濃度 $100 \mathrm{ppm}$ を達成するため, 粒子径 $100 \mathrm{~nm}$ 以下で Gd 含量の高いLE 製剂の調製を検討した。さらに腹 腔内投与後の体内動態を悪性黒色腫細胞 $\left(D_{1}-179\right)$ 担 癌ハムスターを用いて検討した。大豆油，水素添加卵 黄ホスファチジルコリン (HEPC) とGd-DTPA-SA の 3 成分を基本処方とし，薄膜法と水浴式超音波法を 組み合わせて LE を調製した。大豆油，水，HEPC， 
Gd-DTPA-SA の重量比が $7.36: 92: 2: 1$ の基本処方

(Plain LE) に補助界面活性剂（co-surfactant）とし て静脈内投与可能な HCO-60 あるいはポリオキシエ チレン 100-ステアリルエーテル (Brij 700) を補助 界面活性剂重量比 (co-surfactant/ HEPC + GdDTPA-SA） 0.67 以上添加することで，粒子径を 100 nm 以下に減少できた（Table 1)。さらにHCO-60の 場合, HEPC とGd-DTPA-SA の重量比を基本（標 準 $\mathrm{Gd}$ ) 処方の $2: 1$ から高 $\mathrm{Gd}$ 処方の $1: 2$ 人d 含量 を高めても粒子径は $78.7 \mathrm{~nm}$ とどまった（Table 1)。 標準 Gd 含量 HCO-60 およびBrij 700 LE 投与群の 血中, 腫瘍内 Gd 濃度は Plain LE 投与群より有意に 高く、Brij 700 LE 投与群では高い血中 Gd 濃度が長 期にわたり維持された（Fig. 1)。高 Gd 含量 HCO-60 $\mathrm{LE}$ 投与群で, 腫瘍内 $\mathrm{Gd}$ 濃度 $107 \mathrm{ppm}$ と目標の腫瘍 内 Gd 濃度が達成できた。この結果は, 本 LE を用い ることで in vivo で抗腫瘍効果が期待できることを示 唆するものである。

\section{4. 研究を終えて}

本研究では，Gd-DTPA-DM MC を用いた in vivo 試験より, 腫場細胞近傍のみに存在する Gd が NCR を起こしても腫瘍細胞殺傷効果が得られることを明ら かにした。この知見を基に，GdリザーバーMC と $\mathrm{Gd}$ 含有 $\mathrm{LE}$ 製剂の開発を試みた。これら Gd 製剂を 用いることで, GdNCT の in vivo での抗腫瘍効果 (特 に固形癌における), さらに臨床応用へつながること が期待される。

最後に本研究を遂行するにあたり，終始暖かい激励 と示唆に富む討議を通してご指導下さいました神戸学 院大学・薬学部福森義信教授並びに市川秀喜助手, ま た本研究を始める機会を与えて下さいました，筑波大 学臨床医学系秋根康之教授（元国立がんセンター中央 病院放射線科）に深く感謝の意を表します。

(学位取得は1999年 9 月, 神戸学院大学)

四分法原稿

募 集 中

会誌がお手元に届くと，まず「四分法」という方が多いようです。

この人気ある四分法に気軽にご投稿されませんか!

文字数 500 〜 550 字以内で, 内容はできるかぎり“粉”に関連したものが

望ましいのですが, 限定はいたしません。

ご投稿を心よりお待ちしております。 